\title{
Effects of dietary supplementation with quebracho tannins on oxidation parameters and shelf life of lamb meat
}

\author{
Sthefany Kamile dos SANTOS ${ }^{1}$ (D), Michele ROSSET², Marcela Maíra MIQUELETTO ${ }^{1}$, \\ Rebecca Mayre Miranda de JESUS ${ }^{1}$, Cristina Santos SOTOMAIOR ${ }^{1}$, Renata Ernlund Freitas de MACEDO ${ }^{1 *}$
}

\begin{abstract}
The physicochemical quality parameters of meat from finishing lambs supplemented with quebracho tannin extract (QTE) were evaluated. Lambs were assigned to four treatment groups: CON—animals fed basal diet (BD); QTE $1 \%(\mathrm{~T} 1 \%)-\mathrm{BD}+$ tannins at $1 \%$ dry matter intake (DMI); QTE 3\% (T3\%) - BD + tannins at 3\% DMI; and QTE 6\% (T6\%)-BD + tannins at 6\% DMI. Longissimus thoracis et lumborum samples were vacuum packaged and stored at $4{ }^{\circ} \mathrm{C}$ for 28 days. The samples were evaluated weekly for proximate composition, $\mathrm{pH}$, color, myoglobin forms, cooking loss, shear force, lipid (thiobarbituric acid reactive substances-TBARS), and protein (carbonyl and thiol) oxidation. Chemical composition and pH did not vary among treatments. The meat from lambs fed with higher proportion of QTE (T6\%) presented lower redness, chroma, and oxymyoglobin content, and higher yellowness, hue angle, cooking loss, shear force, TBARS, and carbonyl content than the meat from the other groups. Our findings indicate that higher dose of QTE may exert pro-oxidative effects in lamb meat, negatively affecting its quality.
\end{abstract}

Keywords: color; condensed tannin; Schinopsis lorenzii; sheep; tenderness.

Practical Application: Quebracho extract did not delay myoglobin, lipid, and protein oxidation in lamb meat.

\section{Introduction}

Oxidative processes are one of the main causes of deterioration in red meat during storage. The color and flavor of meat are important sensory attributes that influence customers' purchase decision (Zhong et al., 2016). The above characteristics are negatively affected by oxidative processes.

In meat, lipid oxidation results in the production of free radicals, leading to the formation of rancid odors and off-flavors and promoting myoglobin oxidation with color deterioration (Domínguez et al., 2019). In addition, oxidation is responsible for protein fragmentation and aggregation, decreasing protein solubility and reducing enzyme activity, which decreases meat tenderness and results in nutritional value loss (Jerónimo et al., 2016; Lund et al., 2011; Muíño et al., 2014).

Thus, strategies to minimize oxidation and extend the shelf life of meat have been proposed. Recent investigations, aligned with the trends of consuming natural and healthy food products, have focused on the use of natural compounds as antioxidants (Jung et al., 2010; Kumar et al., 2015). In this regard, secondary phenolic compounds from plants, such as condensed tannins (CT), may have antioxidant effects, which could minimize meat oxidation and help maintain nutritional value and sensory characteristics of meat (Kumar et al., 2015).

CT are polymers of flavonoid units linked by strong carboncarbon bonds (Bhatla, 2018). Being polyphenols and due its high degree of hydroxylation of aromatic rings, CT may present a good antioxidant potential acting as primary (donating electrons or hydrogen atoms) or secondary antioxidants (forming complexes with proteins and other macromolecules, and inhibiting prooxidants enzymes) (Koleckar et al., 2008).

The specific antioxidant mechanism of CT in meat systems is not well established, because the direct antioxidant activity would assume its absorption along the gastrointestinal tract and its deposition in the tissues (Luciano et al., 2011). However, the degradation and absorption rate of CT seems to be very low or null (Makkar et al., 1995; López-Andrés et al., 2013). Thus, the beneficial effect of CT seems to be related to the ability to form complexes, exerting an antioxidant effect in the gastrointestinal tract by removing or chelating pro-oxidant compounds or participating in the regeneration of other antioxidant species (López-Andrés et al., 2013).

Although there are studies on the effects of supplementation with CT of different sources and concentrations on animal intake, feed digestibility, and performance (Al-Dobaib, 2009; Deaville et al., 2010; Copani et al., 2013; Yisehak et al., 2014; Liu et al., 2016; Kamel et al., 2018), the studies evaluating CT as a food additive instead of substituting regular ingredients of the diet with tanniniferous plants are quite scarce, and little has been published on effect of CT on meat quality and shelf life. The aim of this study was to assess whether different doses of tannins from quebracho extract (a commercial source of CT that 
is produced from quebracho trees- Schinopsis spp.), added to finishing lambs diet were able to enhance meat quality and shelf life by delaying lipid and protein oxidation - the major cause of chemical spoilage in meat.

\section{Materials and methods}

\subsection{Animals and diets}

This study was approved by the Ethical Committee on the Use of Animals of the Pontifical Catholic University of Paraná (protocol number 01133/2017).

The supplementation with quebracho extract as a source of CT (commercial extract of Quebracho Colorado-Schinopsis lorenzii, 70\% tannins; SilvaFeed-Bypro, Silvateam-Inudor S.A., Argentina) in finishing lambs diet was performed during 49 days from February to March 2018 and 42 days from March to April 2019 using 24 animals in each trial.

Forty-eight lambs (Texel, Suffolk, and Hampshire Down crossbreds) with $112 \pm 12$ (mean \pm SD) days of age and average initial body weight (BW) of $27.0 \pm 3.7 \mathrm{~kg}$ were homogenously assigned by weight, age, and sex to four treatment groups with six repetitions each, where each repetition (experimental unit) was a pen with a male and a female lamb (factorial arrangement $4 \times 6$ ). After a 7-day period of adaptation to the facilities, animals were divided into the following groups: Control (CON) - animals fed with basal diet (BD) without supplementation with quebracho extract (QTE); QTE 1\% (T1\%)-BD + tannins at 1\% dry matter intake (DMI); QTE 3\% (T3\%)-BD + tannins at 3\% DMI; and QTE 6\% (T6\%)-BD + tannins at 6\% DMI. Considering the guaranteed level of $70 \%$ tannins in the product, the amount of QTE was adjusted so that each group received $10 \mathrm{~g}, 30 \mathrm{~g}$, and $60 \mathrm{~g}$ of tannins per kg DMI, respectively.

During the first trial (2018), one lamb from CON was removed from the experiment due to injury.

The basal diet was isoproteic and isoenergetic and composed of corn silage and commercial balanced concentrate (dry matter: 32.9 and $88.0 \%$; crude protein: 8.3 and $16.0 \%$; fat: 3.0 and 3.0\%; ash: 3.1 and 12.0\%; acid detergent fiber: 21.0 and 19.0; neutral detergent fiber: 39.9 and not informed, for silage and concentrate, respectively). The roughage was offered $a d$ libitum with daily adjustment based on $10 \%$ refusals, and the concentrate was offered based on $1.5 \%$ of body weight (as fedbasis) and adjusted weekly according to the live weight changes during the finishing period.

\subsection{Slaughter procedure and meat analysis}

At the end of the feeding period, the heaviest lamb of each repetition (average final body weight $35.4 \pm 0.8 \mathrm{~kg}$, six lambs per group) was slaughtered after fasting $(\sim 18 \mathrm{~h})$ in a commercial abattoir following standard protocols (Brasil, 2000). The animals were selected based on the requirements of live weight stated by the commercial abattoir; thus, the number of slaughtered male/female lambs from each group was $5 / 1,4 / 3,3 / 3$, and $4 / 2$ for $\mathrm{CON}, \mathrm{T} 1 \%, \mathrm{~T} 3 \%$, and $\mathrm{T} 6 \%$, respectively.
Twenty-four hours after refrigeration of the carcasses at $4{ }^{\circ} \mathrm{C}$, longissimus thoracis et lumborum (LTL) muscles from both sides of the carcass were removed (day $0-D 0$ ) and sliced to produce 40 subsamples in total per group. The subsamples were randomized, vacuum packaged, and refrigerated at $4{ }^{\circ} \mathrm{C}$ for $0,7,14,21$, and 28 days (D0, D7, D14, D21, and D28). At each day of analysis, eight subsamples per group were used: four to determine cooking loss and shear force, and the other four for the $\mathrm{pH}$, instrumental color, proximal composition, and oxidation analysis.

Physical-chemical analysis was performed weekly (D0, D7, D14, D21, and D28) as described below.

\subsection{Chemical composition}

Chemical composition (moisture, protein, ash, and fat content) of LTL meat was determined on D0 samples following the official standard method (Association of Official Analytical Chemists, 2016). The results are expressed in $\mathrm{g} / 100 \mathrm{~g}$.

\section{$2.4 \mathrm{pH}$}

The $\mathrm{pH}$ of meat samples was measured at three different points using a $\mathrm{pH}$-meter with an insertion electrode specific for meat products (Hanna, model HI 99163) calibrated at pH 4.0 and 7.0.

\subsection{Cooking loss and shear force}

The samples were weighted and individually placed in a heat resistant plastic bag to be cooked in boiling water until the internal temperature reached $70{ }^{\circ} \mathrm{C}$. Then, the samples were removed from the bag, dried with absorbent paper, and allowed to cool to room temperature to be re-weighted. Cooking loss (CL) was expressed as a percentage of the initial weight (Zhao et al., 2017).

To determine shear force (SF), five $1.27-\mathrm{cm}$-diameter cores parallel to the muscle fibers were removed from the cooked meat. Each core was evaluated in a texture analyzer (model TA.XTplus Texture Analyzer, Stable Micro Systems) equipped with a Warner-Bratzler cell. Shear force (SF) was measured perpendicular to the muscle fiber orientation with a crosshead speed of $3.33 \mathrm{~mm} / \mathrm{s}$ (American Meat Science Association, 2015). The peak SF was expressed in Newton $(\mathrm{N})$.

\subsection{Instrumental color}

Meat samples were removed from the vacuum package and color measurements were performed after 30 minutes of blooming. Three consecutive measurements representing the entire surface of each sample were recorded. CIE color coordinates ( $\mathrm{L}^{*}$, lightness; $\mathrm{a}^{*}$, redness; and $\mathrm{b}^{*}$, yellowness) were measured using a Minolta CR410 portable colorimeter. A D65 illuminant, aperture diameter of $50-53 \mathrm{~mm}$, and $2^{\circ}$ angle of observation were used. Hue angle (discoloration) was calculated as $\mathrm{h}^{*}=\operatorname{arctangent}\left(\mathrm{b}^{*} / \mathrm{a}^{*}\right)$, and chroma (saturation) was calculated as $\mathrm{C}^{\star}=\left(\mathrm{a}^{\star 2}+\mathrm{b}^{\star 2}\right)^{1 / 2}$ (American Meat Science Association, 2012).

Chemical forms of myoglobin were characterized using reflectance methodology via selected wavelengths using a CM$600 \mathrm{D}$ spectrophotometric colorimeter (Konica Minolta Sensing 
Inc.) set to D65 illuminant with an aperture diameter of $8 \mathrm{~mm}$ and $10^{\circ}$ angle of observation. Intermediate reflectance values at $473,525,572$, and $700 \mathrm{~nm}$ obtained in the Specular Component Included (SCI) mode were determined by linear interpolation, and the proportions of deoxymyoglobin (DMb), metmyoglobin $(\mathrm{MMb})$, and oxymyoglobin (OMb) were calculated. The proportions of myoglobin chemical forms were expressed as a percentage (\%) according to American Meat Science Association guidelines (American Meat Science Association, 2012).

\subsection{Lipid oxidation}

The extent of lipid oxidation was estimated using TBARS (thiobarbituric acid reactive substances) values employing the extraction method described by Vyncke (1970). The absorbance at $538 \mathrm{~nm}$ was measured in three replicates for each sample using a spectrophotometer (Spectrum, Model SP-1105). The results were expressed in $\mathrm{mg}$ of malondialdehyde (MDA)/ $\mathrm{kg}$ sample, using 1,1,3,3-tetramethoxypropane as the standard (0.06-1.5 $\mu \mathrm{M})$.

\subsection{Protein oxidation}

Protein oxidation was evaluated by quantification of carbonyl and thiol content, and each sample was evaluated in three replicates.

Thiol content was determined spectrophotometrically by derivatization with Ellman's reagent, DTNB. Extraction of protein was performed according to Jongberg et al. (2011), and thiol determination was performed according to Jongberg et al. (2013) with some modifications; $0.5 \mathrm{~mL}$ of sample was mixed with $0.75 \mathrm{~mL}$ of $5 \%$ SDS/TRIS buffer and $0.05 \mathrm{~mL}$ of $10 \mathrm{mM}$ DTNB dissolved in $0.10 \mathrm{M}$ TRIS buffer. A solution containing $1.25 \mathrm{~mL}$ $5 \%$ SDS/TRIS buffer and $0.05 \mathrm{~mL} 10 \mathrm{mM}$ DTNB was used as a blank. Thiol content was calculated using an absorption coefficient of $14.150 \mathrm{mM}^{-1} \mathrm{~cm}^{-1}$ and expressed in $\mathrm{nmol}$ thiol/ $\mathrm{mg}$ protein.

To measure carbonyl content, myofibrillar proteins were extracted according to Jongberg et al. (2013) with some modifications. Briefly, $3 \mathrm{~g}$ of meat was homogenized in $20 \mathrm{~mL}$ isolation buffer in a series of four centrifugations ( $3000 \mathrm{~g}$ at $4{ }^{\circ} \mathrm{C}$ for $15 \mathrm{~min}$ ). Prior to the last centrifugation, the pellet was resuspended in $10 \mathrm{~mL} 100 \mathrm{mM} \mathrm{NaCl}$, homogenized, and filtered through a voile fabric. The obtained pellets were diluted in $5 \mathrm{~mL}$ of deionized water. Carbonyl content was quantified by the colorimetric method described by Colombo et al. (2016). Protein carbonyl content was calculated using an absorption coefficient of $22.000 \mathrm{M}^{-1} \mathrm{~cm}^{-1}$ and expressed in nmol carbonyl/mg protein.

\subsection{Statistical analysis}

Two trials were carried out in different years. Fixed effects for full models included treatment (CON, T1\%, T3\%, and T6\%), storage time (days $0,7,14,21$, and 28), and their interaction. Year of trial was included as a random term. Data were analyzed by analysis of variance (ANOVA), and the observed means were compared by Tukey's test $(P<0.05)$ and presented with standard error of the mean (mean \pm SEM). Statistical analysis was performed using the software Statgraphics Centurion XVI for Windows (v. 16.1.11).

\section{Results}

\subsection{Chemical composition and $\mathrm{pH}$}

No differences in chemical composition were observed between groups $(P>0.05)$. The mean values of the chemical composition for lamb meat were the following: moisture $70.23 \pm 0.61 \mathrm{~g} / 100 \mathrm{~g}$, protein $18.90 \pm 0.86 \mathrm{~g} / 100 \mathrm{~g}$, fat $2.90 \pm 0.36 \mathrm{~g} / 100 \mathrm{~g}$, and ash $1.09 \pm 0.01 \mathrm{~g} / 100 \mathrm{~g}$.

There was no interaction between treatment and storage time for $\mathrm{pH}(P>0.05)$. No significant differences in $\mathrm{pH}$ were observed among treatments $(P>0.05)$. During storage, D0 and D21 samples had lower $\mathrm{pH}$ values than D7 and D14 samples $(P<0.05)$, although the $\mathrm{pH}$ values did not vary greatly, ranging from 5.53 to 5.64 (Table 1 ).

\subsection{Cooking loss and shear force}

For CL, the interaction between treatment and storage period was not significant $(P>0.05)$, and higher values of cooking loss were observed on D0 and D28 compared to the other sampling times $(P<0.05)$. T6\% showed higher loss than T1\% $(P<0.05)$ and both were similar to CON and T3\% (Table 1).

For shear force, there was an interaction between treatment and storage time $(P<0.05)$. CON and T6\% showed higher SF than other treatments, whereas SF decreased during storage time (Table 1) $(P<0.05)$.

\subsection{Instrumental color}

As shown in Table 2, color parameters were affected by storage time. $L^{*}, b^{*}$, and $h^{*}$ values increased over storage time, whereas $\mathrm{a}^{\star}$ and $\mathrm{C}^{\star}$ decreased $(P<0.05)$. Treatment had no effect on $\mathrm{L}^{\star}$ values $(P>0.05)$; however, $\mathrm{a}^{\star}, \mathrm{b}^{\star}, \mathrm{C}^{\star}$, and $\mathrm{h}^{\star}$ were affected. Color values varied among treatments during storage; in general, T6\% showed lower $\mathrm{a}^{*}$ and $\mathrm{C}^{*}$ values and higher $\mathrm{b}^{\star}$ and hue values than $\mathrm{CON}, \mathrm{T} 1 \%$, and $\mathrm{T} 3 \%$.

Interaction between treatment and storage time was significant for $\mathrm{b}^{\star}$ and $\mathrm{h}^{\star}(P<0.05)$. In this regard, higher QTE supplementation of lamb diet and longer storage time increased yellowness and discoloration (hue) of meat.

With regard to the myoglobin chemical forms percentage (Table 3), there was significant interaction between treatment and storage time for $\mathrm{MMb}(P<0.05)$. OMb content was lower in $\mathrm{T} 6 \%$ than in $\mathrm{T} 3 \%$ and $\mathrm{CON}$, which was reflected in lower redness and chroma values observed in T6\% meat samples. $\mathrm{MMb}$ and $\mathrm{DMb}$ were not affected by treatment. There was an increase in $\mathrm{MMb}$ and $\mathrm{OMb}$ content during storage and a decrease in $\mathrm{DMb}$ content.

\subsection{Lipid and protein oxidation}

Oxidation parameters were affected by treatment and storage time $(P<0.05)$. During storage, there was an increase in TBARS and carbonyl values and a decrease in thiol values (Table 4).

Regarding lipid oxidation, T6\% showed higher values than CON, T1\%, and T3\% $(P<0.05)$. Similarly, carbonyl values were higher in $\mathrm{T} 6 \%$, whereas $\mathrm{CON}$ showed the lowest values. Thiols content was higher in T6\% than in T1\% and T3\%. 
Table 1. Effect of supplementing finishing lambs with different doses of quebracho tannin on pH, cooking loss (CL), and shear force (SF) of meat during storage at $4{ }^{\circ} \mathrm{C}$.

\begin{tabular}{|c|c|c|c|c|c|c|c|}
\hline \multirow{2}{*}{ Parameter } & \multirow{2}{*}{ Treatment } & \multicolumn{5}{|c|}{ Storage time (days) } & \multirow{2}{*}{ Mean } \\
\hline & & 0 & 7 & 14 & 21 & 28 & \\
\hline \multirow[t]{5}{*}{$\mathrm{pH}$} & $\mathrm{CON}$ & $5.54 \pm 0.09$ & $5.64 \pm 0.02$ & $5.59 \pm 0.54$ & $5.57 \pm 0.44$ & $5.49 \pm 0.61$ & $5.57 \pm 0.19^{\mathrm{a}}$ \\
\hline & $\mathrm{T} 1 \%$ & $5.51 \pm 0.06$ & $5.64 \pm 0.54$ & $5.59 \pm 0.54$ & $5.60 \pm 0.47$ & $5.54 \pm 0.02$ & $5.57 \pm 0.18^{\mathrm{a}}$ \\
\hline & $\mathrm{T} 3 \%$ & $5.54 \pm 0.07$ & $5.62 \pm 0.01$ & $5.65 \pm 0.31$ & $5.48 \pm 0.53$ & $5.63 \pm 0.44$ & $5.58 \pm 0.20^{\mathrm{a}}$ \\
\hline & T6\% & $5.57 \pm 0.04$ & $5.65 \pm 0.31$ & $5.65 \pm 0.54$ & $5.50 \pm 0.43$ & $5.53 \pm 0.31$ & $5.58 \pm 0.16^{\mathrm{a}}$ \\
\hline & Mean & $5.54 \pm 0.01^{\mathrm{C}}$ & $5.64 \pm 0.16^{\mathrm{A}}$ & $5.62 \pm 0.25^{\mathrm{AB}}$ & $5.53 \pm 0.24^{\mathrm{C}}$ & $5.55 \pm 0.21^{\mathrm{BC}}$ & \\
\hline \multirow{4}{*}{ CL (\%) } & $\mathrm{T} 1 \%$ & $25.5 \pm 1.1$ & $25.1 \pm 1.4$ & $22.2 \pm 2.1$ & $24.4 \pm 3.0$ & $29.2 \pm 2.3$ & $25.3 \pm 1.1^{\mathrm{b}}$ \\
\hline & Т3\% & $30.3 \pm 1.2$ & $25.0 \pm 2.0$ & $26.2 \pm 1.4$ & $23.6 \pm 2.6$ & $29.3 \pm 4.0$ & $26.9 \pm 1.2^{\mathrm{ab}}$ \\
\hline & $\mathrm{T} 6 \%$ & $33.4 \pm 1.6$ & $29.0 \pm 2.2$ & $25.7 \pm 2.4$ & $26.5 \pm 1.1$ & $32.7 \pm 1.5$ & $29.4 \pm 1.1^{\text {a }}$ \\
\hline & Mean & $29.8 \pm 0.0^{\mathrm{A}}$ & $25.5 \pm 1.1^{\mathrm{B}}$ & $25.6 \pm 1.1^{\mathrm{B}}$ & $24.6 \pm 1.4^{\text {B }}$ & $30.7 \pm 1.3^{\mathrm{A}}$ & \\
\hline $\mathrm{SF}(\mathrm{N})$ & $\mathrm{CON}$ & $78.8 \pm 7.1^{\mathrm{aA}}$ & $21.5 \pm 1.1^{\mathrm{abB}}$ & $25.0 \pm 1.7$ ав & $20.0 \pm 1.0^{\mathrm{aB}}$ & $22.0 \pm 1.0^{\mathrm{bB}}$ & $34.7 \pm 2.4^{\mathrm{a}}$ \\
\hline
\end{tabular}

CON: Basal diet (BD); T1\%: BD + quebracho tannins at 1\% dry matter intake (DMI); T3\%: BD + quebracho tannins at 3\% DMI; T6\%: BD + quebracho tannins at 6\% DMI. Different lowercase letters in the column (Treatment) and uppercase letters in the row (Storage time) differ by Tukey's test $(\mathrm{P}<0.05)$. Interaction between treatment and storage time $(P<0.05)$ for $\mathrm{SF}$.

Table 2. Effect of supplementing finishing lambs with different doses of quebracho tannin on instrumental color of meat during storage at $4{ }^{\circ} \mathrm{C}$.

\begin{tabular}{|c|c|c|c|c|c|c|c|}
\hline \multirow{2}{*}{ Parameter } & \multirow{2}{*}{ Treatment } & \multicolumn{5}{|c|}{ Storage time (days) } & \multirow{2}{*}{ Mean } \\
\hline & & 0 & 7 & 14 & 21 & 28 & \\
\hline \multirow[t]{5}{*}{$\mathrm{L}^{*}$} & $\mathrm{CON}$ & $44.1 \pm 3.5$ & $45.2 \pm 2.5$ & $46.2 \pm 0.4$ & $46.5 \pm 4.5$ & $47.7 \pm 0.6$ & $45.9 \pm 1.3^{\mathrm{a}}$ \\
\hline & $\mathrm{T} 1 \%$ & $43.8 \pm 4.9$ & $44.5 \pm 1.1$ & $46.0 \pm 1.1$ & $44.0 \pm 3.7$ & $47.3 \pm 0.3$ & $45.2 \pm 1.3^{\mathrm{a}}$ \\
\hline & $\mathrm{T} 3 \%$ & $45.3 \pm 2.6$ & $43.5 \pm 6.4$ & $46.1 \pm 0.6$ & $45.8 \pm 0.7$ & $46.5 \pm 0.8$ & $45.6 \pm 1.5^{\mathrm{a}}$ \\
\hline & $\mathrm{T} 6 \%$ & $45.2 \pm 0.5$ & $44.5 \pm 0.8$ & $45.4 \pm 0.6$ & $47.9 \pm 0.7$ & $46.5 \pm 4.5$ & $45.9 \pm 0.9^{\mathrm{a}}$ \\
\hline & Mean & $44.7 \pm 0.0^{\mathrm{BC}}$ & $44.5 \pm 1.8^{\mathrm{C}}$ & $45.9 \pm 0.4^{\mathrm{AB}}$ & $46.3 \pm 1.4^{\mathrm{A}}$ & $47.0 \pm 1.2^{\mathrm{A}}$ & \\
\hline \multirow[t]{5}{*}{$a^{*}$} & $\mathrm{CON}$ & $21.3 \pm 0.6$ & $22.0 \pm 1.3$ & $22.7 \pm 0.3$ & $18.1 \pm 0.5$ & $18.5 \pm 0.4$ & $20.5 \pm 0.4^{\mathrm{a}}$ \\
\hline & $\mathrm{T} 1 \%$ & $21.1 \pm 0.5$ & $21.1 \pm 0.5$ & $20.5 \pm 0.6$ & $16.6 \pm 0.9$ & $17.5 \pm 0.4$ & $19.6 \pm 0.3^{b}$ \\
\hline & $\mathrm{T} 3 \%$ & $21.2 \pm 0.5$ & $22.1 \pm 1.8$ & $21.9 \pm 0.6$ & $17.4 \pm 0.7$ & $18.8 \pm 0.3$ & $20.2 \pm 0.4^{\mathrm{a}}$ \\
\hline & $\mathrm{T} 6 \%$ & $21.7 \pm 0.3$ & $21.1 \pm 0.4$ & $21.2 \pm 0.4$ & $15.4 \pm 0.8$ & $15.8 \pm 0.5$ & $19.0 \pm 0.4^{b}$ \\
\hline & Mean & $21.3 \pm 0.0^{\mathrm{A}}$ & $21.5 \pm 0.6^{\mathrm{A}}$ & $21.6 \pm 0.3^{A}$ & $16.9 \pm 0.4^{\mathrm{B}}$ & $17.6 \pm 0.2^{\mathrm{B}}$ & \\
\hline \multirow[t]{5}{*}{$b^{*}$} & $\mathrm{CON}$ & $5.2 \pm 0.3^{\mathrm{bD}}$ & $6.8 \pm 0.2^{\mathrm{aC}}$ & $7.7 \pm 0.4^{\mathrm{aAB}}$ & $6.9 \pm 0.2 \mathrm{aBC}$ & $8.1 \pm 0.8^{\text {aA }}$ & $6.9 \pm 0.2^{\mathrm{a}}$ \\
\hline & $\mathrm{T} 1 \%$ & $6.0 \pm 0.6^{\mathrm{abA}}$ & $6.1 \pm 0.3^{\mathrm{aA}}$ & $6.4 \pm 0.4^{\mathrm{bA}}$ & $5.8 \pm 0.6^{\mathrm{bA}}$ & $7.0 \pm 0.2^{\mathrm{bA}}$ & $6.3 \pm 0.2^{b}$ \\
\hline & $\mathrm{T} 3 \%$ & $6.2 \pm 0.2^{\mathrm{aA}}$ & $6.8 \pm 0.2^{\mathrm{aA}}$ & $6.7 \pm 0.4 \mathrm{abA}$ & $6.3 \pm 0.2^{\mathrm{abA}}$ & $6.9 \pm 0.2^{\mathrm{bA}}$ & $6.6 \pm 0.1^{\mathrm{ab}}$ \\
\hline & $\mathrm{T} 6 \%$ & $6.3 \pm 0.4^{\mathrm{aBC}}$ & $6.0 \pm 0.2^{\mathrm{aC}}$ & $7.0 \pm 0.4^{\mathrm{abAB}}$ & $7.1 \pm 0.2^{\mathrm{aAB}}$ & $7.4 \pm 0.3^{\mathrm{bA}}$ & $6.8 \pm 0.2^{a}$ \\
\hline & Mean & $5.9 \pm 0.0^{\mathrm{D}}$ & $6.4 \pm 0.1^{\mathrm{C}}$ & $7.0 \pm 0.2^{\mathrm{AB}}$ & $6.6 \pm 0.2^{\mathrm{BC}}$ & $7.3 \pm 0.2^{\mathrm{A}}$ & \\
\hline \multirow[t]{5}{*}{$\mathrm{C}^{*}$} & $\mathrm{CON}$ & $21.9 \pm 0.7$ & $23.1 \pm 1.3$ & $24.0 \pm 0.3$ & $19.4 \pm 0.5$ & $20.2 \pm 0.4$ & $21.7 \pm 0.4^{\mathrm{a}}$ \\
\hline & $\mathrm{T} 1 \%$ & $22.1 \pm 0.5$ & $22.0 \pm 0.5$ & $21.5 \pm 0.6$ & $17.6 \pm 1.0$ & $18.8 \pm 0.4$ & $20.7 \pm 0.3^{b}$ \\
\hline & T3\% & $22.1 \pm 0.5$ & $23.1 \pm 1.8$ & $22.9 \pm 0.7$ & $18.6 \pm 0.6$ & $20.0 \pm 0.3$ & $21.3 \pm 0.4^{\mathrm{a}}$ \\
\hline & $\mathrm{T} 6 \%$ & $22.5 \pm 0.4$ & $22.0 \pm 0.4$ & $22.3 \pm 0.4$ & $17.1 \pm 0.7$ & $17.5 \pm 0.5$ & $20.3 \pm 0.3^{b}$ \\
\hline & Mean & $22.2 \pm 0.0^{\mathrm{A}}$ & $22.5 \pm 0.6^{\mathrm{A}}$ & $22.7 \pm 0.3^{A}$ & $18.2 \pm 0.4^{\mathrm{B}}$ & $19.1 \pm 0.2^{\text {в }}$ & \\
\hline \multirow[t]{5}{*}{$\mathrm{h}^{*}$} & $\mathrm{CON}$ & $13.7 \pm 0.4^{\mathrm{bC}}$ & $17.3 \pm 0.5^{\mathrm{aB}}$ & $18.8 \pm 1.1 \mathrm{aB}$ & $21.1 \pm 0.8^{\mathrm{bA}}$ & $23.1 \pm 0.5^{\mathrm{abA}}$ & $18.8 \pm 0.5^{b}$ \\
\hline & $\mathrm{T} 1 \%$ & $15.3 \pm 1.2 \mathrm{abC}$ & $16.3 \pm 0.6^{\mathrm{aBC}}$ & $17.4 \pm 0.8 \mathrm{aBC}$ & $18.8 \pm 1.2^{\mathrm{bAB}}$ & $21.3 \pm 2.0^{\mathrm{bcA}}$ & $17.6 \pm 0.6^{b}$ \\
\hline & $\mathrm{T} 3 \%$ & $16.1 \pm 1.0^{\mathrm{aC}}$ & $17.5 \pm 0.5 \mathrm{aBC}$ & $17.0 \pm 0.7^{\mathrm{aC}}$ & $19.3 \pm 1.2^{\mathrm{bAB}}$ & $20.2 \pm 0.5^{\mathrm{cA}}$ & $18.0 \pm 0.4^{b}$ \\
\hline & $\mathrm{T} 6 \%$ & $15.7 \pm 0.4^{\mathrm{aB}}$ & $15.9 \pm 0.5^{\mathrm{aB}}$ & $18.0 \pm 0.5^{\mathrm{aB}}$ & $25.4 \pm 1.5^{\mathrm{aA}}$ & $25.2 \pm 1.1^{\mathrm{aA}}$ & $20.0 \pm 0.6^{\mathrm{a}}$ \\
\hline & Mean & $15.2 \pm 0.0^{\mathrm{C}}$ & $16.8 \pm 0.3^{\text {в }}$ & $17.8 \pm 0.4^{\mathrm{B}}$ & $21.4 \pm 0.7^{\mathrm{A}}$ & $22.5 \pm 0.6^{\mathrm{A}}$ & \\
\hline
\end{tabular}

CON: Basal diet (BD); T1\%: BD + quebracho tannins at 1\% dry matter intake (DMI); T3\%: BD + quebracho tannins at 3\% DMI; T6\%: BD + quebracho tannins at 6\% DMI. Different lowercase letters in the column (Treatment) and uppercase letters in the row (Storage time) differ by Tukey's test $(P<0.05)$. Interaction between treatment and storage time $(\mathrm{P}<0.05)$ for $b^{*}$ and $h^{*}$. 


\section{Discussion}

\subsection{Chemical composition, $p H, C L$, and $S F$}

The addition of quebracho CT to the diet of lambs did not affect the chemical composition of meat. In general, the proximate composition of muscle is influenced by diet. Since the lambs were fed similar basal diets, major differences were not expected in chemical composition. However, conversely to the results of the present study, Vasta et al. (2007) reported lower fat content in meat from lambs receiving diet with carob pulp CT supplementation than in meat from lambs fed without carob pulp CT.

Table 3. Effect of supplementing finishing lambs with different doses of quebracho tannin on the proportion of deoxymyoglobin (DMb), metmyoglobin $(\mathrm{MMb})$, and oxymyoglobin $(\mathrm{OMb})$ in meat during storage at $4{ }^{\circ} \mathrm{C}$.

\begin{tabular}{|c|c|c|c|c|c|c|c|}
\hline \multirow{2}{*}{ Parameter } & \multirow{2}{*}{ Treatment } & \multicolumn{5}{|c|}{ Storage Time (days) } & \multirow{2}{*}{ Mean } \\
\hline & & 0 & 7 & 14 & 21 & 28 & \\
\hline \multirow[t]{5}{*}{$\mathrm{MMb}(\%)$} & $\mathrm{CON}$ & $22.1 \pm 1.2^{\text {bB }}$ & $19.6 \pm 0.4^{\text {bВ }}$ & $23.5 \pm 1.0^{\mathrm{aB}}$ & $31.4 \pm 1.9^{\mathrm{aA}}$ & $33.9 \pm 1.6^{\mathrm{aA}}$ & $26.2 \pm 0.8^{a}$ \\
\hline & $\mathrm{T} 1 \%$ & $27.0 \pm 1.3^{\mathrm{abABC}}$ & $23.7 \pm 1.3 \mathrm{aBC}$ & $22.6 \pm 1.0^{\mathrm{aC}}$ & $29.1 \pm 1.6^{\mathrm{aAB}}$ & $30.7 \pm 1.1^{\mathrm{abA}}$ & $26.2 \pm 0.7^{\mathrm{a}}$ \\
\hline & $\mathrm{T} 3 \%$ & $28.2 \pm 1.3^{\mathrm{aA}}$ & $22.4 \pm 0.4^{\mathrm{abB}}$ & $23.9 \pm 0.7 \mathrm{aB}$ & $27.5 \pm 0.9^{\mathrm{aA}}$ & $27.3 \pm 0.5^{\mathrm{bA}}$ & $25.8 \pm 0.4^{\mathrm{a}}$ \\
\hline & T6\% & $27.2 \pm 1.7^{\mathrm{ab} A \mathrm{~B}}$ & $23.2 \pm 0.6^{\mathrm{aB}}$ & $25.4 \pm 0.9^{\mathrm{aB}}$ & $27.0 \pm 2.9 \mathrm{aAB}$ & $32.1 \pm 1.7^{\mathrm{aA}}$ & $27.0 \pm 0.8^{a}$ \\
\hline & Mean & $26.1 \pm 0.0^{\mathrm{BC}}$ & $22.2 \pm 0.4^{\mathrm{D}}$ & $23.9 \pm 0.5^{\mathrm{CD}}$ & $28.8 \pm 1.0^{\mathrm{AB}}$ & $31.0 \pm 0.7^{\mathrm{A}}$ & \\
\hline \multirow[t]{5}{*}{$\mathrm{DMb}(\%)$} & $\mathrm{CON}$ & $41.8 \pm 3.1$ & $29.8 \pm 1.6$ & $15.1 \pm 1.1$ & $13.2 \pm 1.6$ & $8.4 \pm 0.8$ & $21.2 \pm 1.5^{\mathrm{a}}$ \\
\hline & $\mathrm{T} 1 \%$ & $36.4 \pm 1.2$ & $29.5 \pm 2.6$ & $22.6 \pm 2.5$ & $15.9 \pm 1.8$ & $10.4 \pm 1.0$ & $23.7 \pm 1.4^{\mathrm{a}}$ \\
\hline & $\mathrm{T} 3 \%$ & $37.5 \pm 2.0$ & $29.0 \pm 1.7$ & $21.0 \pm 2.3$ & $13.4 \pm 1.3$ & $13.3 \pm 0.9$ & $22.5 \pm 1.2^{\mathrm{a}}$ \\
\hline & $\mathrm{T} 6 \%$ & $42.5 \pm 3.2$ & $33.7 \pm 2.0$ & $23.2 \pm 1.3$ & $15.9 \pm 2.9$ & $9.5 \pm 1.8$ & $24.8 \pm 1.6^{\mathrm{a}}$ \\
\hline & Mean & $39.6 \pm 0.0^{\mathrm{A}}$ & $30.5 \pm 1.0^{\mathrm{B}}$ & $20.5 \pm 1.0^{\mathrm{C}}$ & $14.4 \pm 1.0^{\mathrm{D}}$ & $10.4 \pm 0.6^{\mathrm{E}}$ & \\
\hline \multirow[t]{5}{*}{$\mathrm{OMb}(\%)$} & $\mathrm{CON}$ & $36.1 \pm 3.8$ & $50.6 \pm 1.4$ & $61.3 \pm 0.6$ & $55.4 \pm 1.5$ & $57.7 \pm 1.2$ & $52.6 \pm 1.2^{\mathrm{a}}$ \\
\hline & $\mathrm{T} 1 \%$ & $36.5 \pm 2.1$ & $46.8 \pm 2.4$ & $54.8 \pm 1.9$ & $55.0 \pm 2.4$ & $58.9 \pm 1.0$ & $50.1 \pm 1.3^{\mathrm{ab}}$ \\
\hline & T3\% & $34.2 \pm 1.6$ & $48.6 \pm 1.8$ & $55.2 \pm 2.1$ & $59.1 \pm 1.2$ & $59.4 \pm 1.1$ & $51.7 \pm 1.2^{\mathrm{a}}$ \\
\hline & T6\% & $30.3 \pm 3.5$ & $43.1 \pm 1.5$ & $51.3 \pm 1.3$ & $57.1 \pm 2.3$ & $58.4 \pm 1.7$ & $48.2 \pm 1.5^{b}$ \\
\hline & Mean & $34.3 \pm 0.0^{\mathrm{C}}$ & $47.3 \pm 1.0^{\mathrm{B}}$ & $55.7 \pm 0.9^{\mathrm{A}}$ & $56.8 \pm 0.9^{\mathrm{A}}$ & $58.6 \pm 0.7^{\mathrm{A}}$ & \\
\hline
\end{tabular}

CON: Basal diet (BD); T1\%: BD + quebracho tannins at 1\% dry matter intake (DMI); T3\%: BD + quebracho tannins at 3\% DMI; T6\%: BD + quebracho tannins at 6\% DMI. Different lowercase letters in the column (Treatment) and uppercase letters in the row (Storage time) differ by Tukey's test $(P<0.05)$. Interaction between treatment and storage time $(P<0.05)$ for $\mathrm{MMb}$.

Table 4. Effect of supplementing finishing lambs with different doses of quebracho tannin on lipid (TBARS) and protein (carbonyl and thiol) oxidation of meat stored at $4{ }^{\circ} \mathrm{C}$.

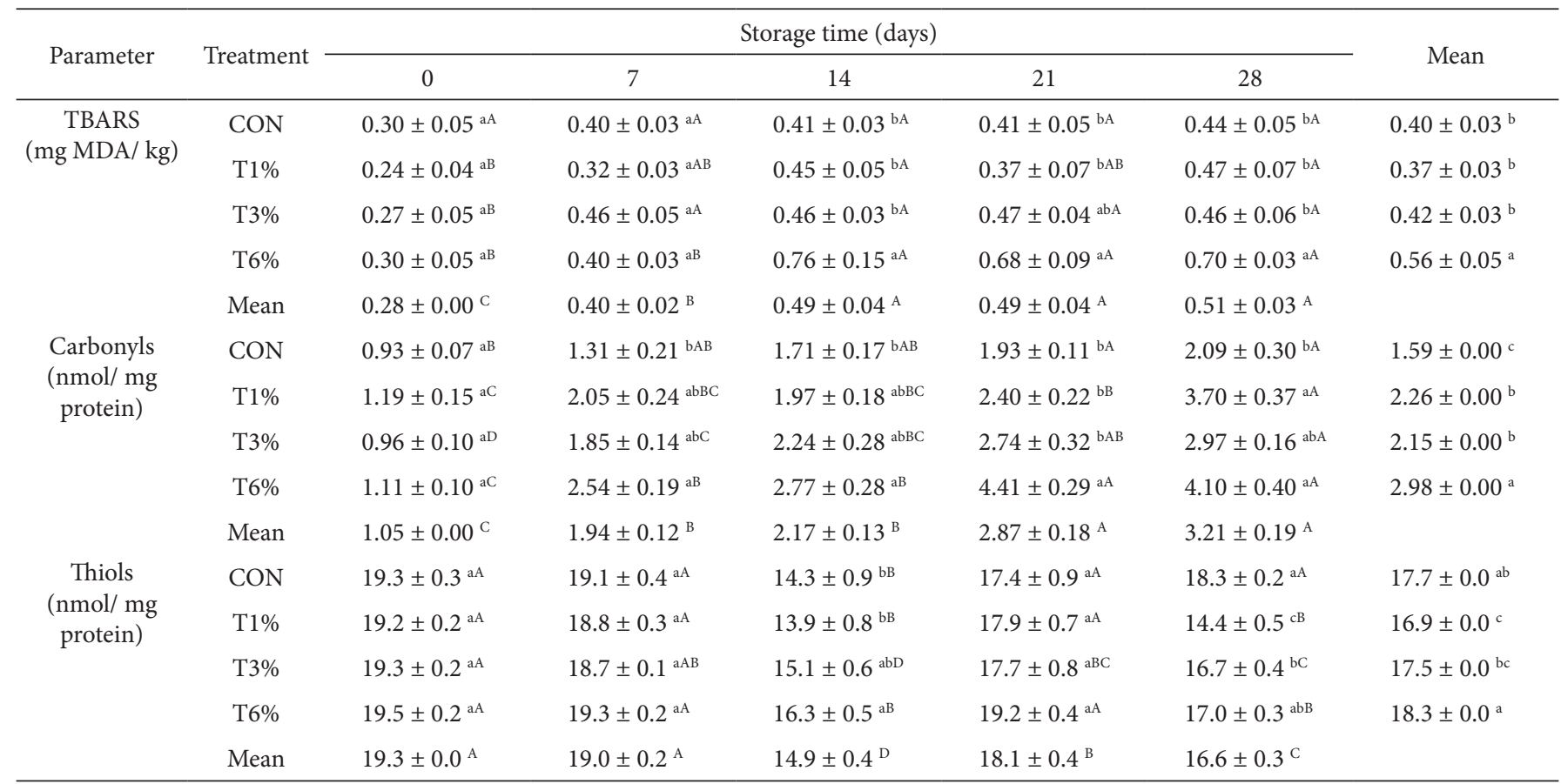

CON: Basal diet (BD); T1\%: BD + quebracho tannins at 1\% dry matter intake (DMI); T3\%: BD + quebracho tannins at 3\% DMI; T6\%: BD + quebracho tannins at 6\% DMI. Different lowercase letters in the column (Treatment) and uppercase letters in the row (Storage time) differ by Tukey's test $(\mathrm{P}<0.05)$. Interaction between treatment and storage period $(P<0.05)$ for TBARS, carbonyls, and thiols. 
In general, the values of $\mathrm{pH}$ in the present study were within range of values for lamb meat, ruling out dark-cutting or stress problems (Carrasco et al., 2009). During storage, the $\mathrm{pH}$ values remained almost constant. Our results are different from those of Stahlke et al. (2019); upon evaluation of vacuum-packed lamb meat, they observed a slight increase in $\mathrm{pH}$ over 35 days, attributing it to autolysis and ageing.

Our $\mathrm{pH}$ results are consistent with those of Lobón et al. (2017), who finished lambs with quebracho and did not find differences in $\mathrm{pH}$ values. However, Priolo et al. (2000) verified that lamb meat from animals fed with CT showed higher $\mathrm{pH}$ values, possibly associated with inadequate nutrient availability.

The $\mathrm{pH}$ value influences many meat quality traits due to the effect on shelf life, color, and quality of the fresh meat (Lee et al., 2017). As pH was within the normal range, it did not affect the technological properties of lamb meat.

Despite the fact that T6\% presented higher CL values than $\mathrm{T} 1 \%$, in general, the values were low for lamb meat in all groups. Similar CL values were reported by Francisco et al. (2015) and Girard et al. (2016). Although the CL values were within normal range, a higher CL in T6\% may have led to a higher SF, because meat with lower water holding capacity tends to be tougher after cooking (Fernandes et al., 2012). Based on the SF values, meat tenderness of T1\% and T3\% was higher, but all treatment groups showed mean values consistent with tender meat. SF is influenced by storage time, and it is expected that an increase in aging time will increase tenderness due to enzymatic activity and decreased strength of the connective tissues (Hopkins, 2017).

\subsection{Instrumental color and chemical forms of myoglobin}

As the percentage of $\mathrm{MMb}$ on the meat surface increases, an increase in $\mathrm{L}^{*}$ values is expected as accumulation of $\mathrm{MMb}$ due to heme pigment oxidation changes the meat color from red to brown (Warner, 2014). In addition, increased values of $L^{\star}$ can be due to protein denaturation, which increases dispersion of light (Warner, 2014). Myoglobin oxidation is also evidenced by decrease in $\mathrm{a}^{\star}$ and $\mathrm{C}^{\star}$ values and increase in $\mathrm{h}^{\star}$ (Gravador et al., 2015), as observed in all groups during storage in the present study.

Higher $b^{\star}$ values are related to higher level of discoloration $\left(h^{\star}\right)$ as observed in T6\%. Similarly, $C^{\star}$ and $a^{\star}$ values are related, thus higher redness promoted higher color saturation as observed in $\mathrm{CON}$ and $\mathrm{T} 3 \%$.

The effect of dietary CT on meat color of lambs is controversial. Priolo et al. (2000) verified that $\mathrm{L}^{*}$ value of longissimus muscle from animals fed tannin-rich diets was similar to that from animals fed a control diet but higher than that of animals fed with propylene glycol to inactivate tannins. In addition, the authors observed that $\mathrm{a}^{*}, \mathrm{~b}^{*}$, and $\mathrm{C}^{\star}$ were not affected by diet, while $\mathrm{h}^{\star}$ increased in tannin-fed lambs. On the other hand, Lobón et al. (2017) supplemented lamb diet with 5\% CT from quebracho and did not observe an effect on meat color coordinates or MMb content in longissimus muscle stored up to 14 days. The results were explained by a short fattening period ( 30 days) and a low dose of CT. Additionally, they suggested that dietary tannins of quebracho are not degraded or absorbed in the gastrointestinal tract.

In the present study, supplementation was carried out during a longer period and different doses of CT were evaluated. Nevertheless, higher level of CT did not influence meat color stability, since color was affected in a different manner for each coordinate. Moreover, higher content of tannins negatively influenced meat color of T6\%, evidenced by higher yellowness and discoloration, and lower redness and chroma than CON and the other groups.

Conversely, Luciano et al. (2009a, b) provided higher doses of quebracho $(8.9 \% \mathrm{DM})$ for 60 days and concluded that the inclusion of tannins improves meat color stability in semimembranosus muscle stored for 14 days; despite general changes, higher $\mathrm{a}^{\star}$ values and lower $b^{\star}$ and $h^{*}$ values were observed in meat of tannin-fed animals. Thus, the use of quebracho condensed tannins to improve meat color stability is controversial and results are not conclusive.

An increase in the proportion of $\mathrm{OMb}$ was observed with prolonged storage time. Aroeira et al. (2017) evaluated beef, vacuum-packed for up to 21 days, and similar results were reported. The authors attributed the results to reduction in the oxygen consumption rate (OCR), which promotes oxygen penetration on the surface of meat. However, an increase in $\mathrm{a}^{\star}$ values and constant levels of $\mathrm{MMb}$ were observed, while in the present study, there was a decrease in $\mathrm{a}^{*}$ values and a concurrent accumulation of $\mathrm{MMb}$.

Despite the increase in $\mathrm{MMb}$ levels throughout the storage time that can negatively affect consumer's acceptability, the mean values observed for $\mathrm{a}^{*}$ and $\mathrm{L}^{*}$ color coordinates (19.5 and 45.6, respectively) were above the threshold of $95 \%$ confidence for a random consumer consider the meat acceptable (14.5 and 44 for $\mathrm{a}^{\star}$ and $\mathrm{L}^{\star}$, respectively) (Khliji et al., 2010).

Increase in $\mathrm{OMb}$ amount may increase redness of meat because $\mathrm{OMb}$ is redder than $\mathrm{DMb}$ and $\mathrm{MMb}$ as stated by Hernández et al. (2016), who evaluated the influence of redox forms of myoglobin on color coordinates of beef. The authors indicated that although reflex attenuation is only weakly correlated with $\mathrm{a}^{*}$, the correlation between the amount of $\mathrm{OMb}$ and redness of meat is positive. However, Lindahl et al. (2001) observed that $\mathrm{OMb}$ did not influence the $\mathrm{a}^{*}$ value in pork meat. Thus, the effect of $\mathrm{OMb}$ on color coordinates of lamb meat needs further investigation.

Increased $\mathrm{OMb}$ amount did not influence meat color appearance as discoloration was observed in all groups, especially in T6\%, which experienced higher myoglobin oxidation, indicated by lower redness and saturation, higher yellowness and discoloration, and higher protein and lipid oxidation as discussed below.

\subsection{Lipid and protein oxidation}

The results of the present study show that moderate doses of dietary tannin (1\% and 3\%) did not prevent lipid oxidation. However, higher amount of CT in the diet seemed to promote oxidation, because T6\% showed higher TBARS value than the other groups. Higher lipid oxidation and lower color stability 
indicated that $6 \%$ CT diet supplementation was not able to prevent oxidation in lamb meat.

Brogna et al. (2014), Lobón et al. (2017), and Luciano et al. (2009b) also observed that CT from quebracho had no effect on lipid oxidation of lamb meat stored for 12 days, 14 days, and 14 days, respectively. Zhong et al. (2016) did not find differences in lipid oxidation in meat (refrigerated 24 hours) from lambs fed with tanniferous sorghum. Valenti et al. (2019) compared chestnut, mimosa, and tara fed lamb meat stored for 7 days and reported similar results.

TBARS increased with storage time but remained below the threshold of perceived rancidity (1 mg MDA/kg of meat) in all treatment groups (Ripoll et al., 2011). Low fat content of lamb meat (fat $2.90 \pm 0.36 \mathrm{~g} / 100 \mathrm{~g}$ of meat) may have contributed to the low TBARS values.

Lipid oxidation in meat likely triggers protein oxidation (Lund et al., 2011). So, similar to an increase in TBARS, an increase in carbonyl and a decrease in free thiol groups indicate that protein oxidation has occurred and increased progressively during storage, and this process could be linked to lipid oxidation that presented the same upward trend.

Lund et al. (2011) described that protein oxidation negatively affects the holding water capacity and tenderness of meat. As T6\% exhibited higher protein oxidation measured by carbonyl formation, the results may help justify the findings observed for SF and CL in this group and reinforce that quebracho CT did not exert an antioxidant effect on meat; instead, a pro-oxidant effect may be suggested.

CT may modify lipid profile in meat, increasing the content of polyunsaturated fatty acids (PUFA) due to interference with microbial biohydrogenation in rumen (Morales \& Ungerfeld, 2015). PUFA are more instable and, thus, more susceptible to oxidation than other fatty acids; their presence may explain why higher doses of quebracho in diet led to greater meat oxidation in the present study.

Kamel et al. (2018) offered CT from quebracho at 2\% or $4 \% \mathrm{DM}$ to lambs and found that CT increased healthy fatty acid content in meat, such as PUFA conjugated linoleic acid. Similarly, Lobón et al. (2017) have added 5\% quebracho and Vasta et al. (2009) 8.93\% DM to the diet of finishing lambs and observed an increase in the total PUFA levels of meat.

However, Gravador et al. (2015) have observed that despite an increase in polyunsaturated fatty acid content in meat of lambs fed with carob pulp, lipid and protein oxidation were unaffected during 6 days of storage, suggesting an antioxidant action of the plant. The researches that used quebracho as a source of condensed tannins did not evaluate protein oxidation, so the comparison of our results with those of other studies was not possible.

Although in the present study the fatty acid composition was not determined, based on the previous studies we assumed that an increase in PUFA content occurred due to the inclusion of QTE into animal diet, partially explaining an increase in meat oxidation for T6\%. Furthermore, even low doses of QTE, such as the ones used in $\mathrm{T} 1 \%$ and $\mathrm{T} 3 \%$, could have changed the fatty acid profile, but our results indicated that this modification was not reflected by increased oxidative instability for these groups.

A few studies have evaluated the effect of quebracho extract added to lamb diet, but to our knowledge, the pro-oxidative behavior was observed only in the present study. Thus, further investigation is needed to explain the above findings.

\section{Conclusion}

The addition of quebracho extract to the diets of lambs at low and intermediate doses of $1 \%$ and $3 \%$ of dry matter intake did not prevent oxidative processes or extend the shelf life of meat. Furthermore, higher doses $(6 \%$ ) have the potential to increase lipid and protein oxidation, negatively affecting the color and tenderness of meat. Our results indicate that quebracho, the way it was used in the present study, does not seem to be a proper source of condensed tannins to improve lamb meat quality.

\section{Acknowledgements}

This study was financed in part by the Coordenação de Aperfeiçoamento de Pessoal de Nível Superior-Brasil (CAPES)Finance Code 001.

\section{References}

Al-Dobaib, S. N. (2009). Effect of different levels of quebracho tannin on nitrogen utilization and growth performance of Najdi sheep fed alfalfa (Medicago sativa) hay as a sole diet. Animal Science Journal, 80(5), 532-541. http://dx.doi.org/10.1111/j.1740-0929.2009.00662.x. PMid:20163617.

American Meat Science Association - AMSA. (2012). Meat color measurement guidelines. Champaign: AMSA.

American Meat Science Association - AMSA. (2015). Research guidelines for cookery, sensory evaluation, and instrumental tenderness measurements of meat. Champaign: AMSA.

Aroeira, C. N., Torres, R. A. Fo., Fontes, P. R., Ramos, A. D. L. S., Gomide, L. A. M., Ladeira, M. M., \& Ramos, E. M. (2017). Effect of freezing prior to aging on myoglobin redox forms and CIE color of beef from Nellore and Aberdeen Angus cattle. Meat Science, 125, 16-21. http://dx.doi.org/10.1016/j.meatsci.2016.11.010. PMid:27883957.

Association of Official Analytical Chemists - AOAC. (2016). Official methods of analysis (20th ed.). Washington: AOAC.

Bhatla, C. (2018). Secondary metabolites. In S. C. Bhatla \& M. A. Lal (Eds.), Plant physiology, development and metabolism (Chap. 33, pp. 1099-1166). Singapore: Springer Nature. http://dx.doi. org/10.1007/978-981-13-2023-1_33.

Brasil, Ministério da Agricultura, Pecuária e Abastecimento. (2000, January 24). Aprova o Regulamento técnico de métodos de insensibilização para o abate humanitário de animais de açougue (Instrução normativa no 3, de 17 de janeiro de 2000). Diário Oficial [da] República Federativa do Brasil.

Brogna, D. M. R., Tansawat, R., Cornforth, D., Ward, R., Bella, M., Luciano, G., Priolo, A., \& Villalba, J. (2014). The quality of meat from sheep treated with tannin-and saponin-based remedies as a natural strategy for parasite control. Meat Science, 96(2 Pt A), 744-749. http://dx.doi.org/10.1016/j.meatsci.2013.10.019. PMid:24211542. 
Carrasco, S., Panea, B., Ripoll, G., Sanz, A., \& Joy, M. (2009). Influence of feeding systems on cortisol levels, fat colour and instrumental meat quality in light lambs. Meat Science, 83(1), 50-56. http://dx.doi. org/10.1016/j.meatsci.2009.03.014. PMid:20416669.

Colombo, G., Clerici, M., Garavaglia, M. E., Giustarini, D., Rossi, R., Milzani, A., \& Dalle-Donne, I. (2016). A step-by-step protocol for assaying protein carbonylation in biological samples. Journal of Chromatography. B, Analytical Technologies in the Biomedical and Life Sciences, 1019, 178-190. http://dx.doi.org/10.1016/j. jchromb.2015.11.052. PMid:26706659.

Copani, G., Hall, J. O., Miller, J., Priolo, A., \& Villalba, J. J. (2013). Plant secondary compounds as complementary resources: are they always complementary? Oecologia, 172(4), 1041-1049. http://dx.doi. org/10.1007/s00442-012-2551-1. PMid:23223888.

Deaville, E. R., Givens, D. I., \& Mueller-Harvey, I. (2010). Chestnut and mimosa tannin silages: effects in sheep differ for apparent digestibility, nitrogen utilisation and losses. Animal Feed Science and Technology, 157(3-4), 129-138. http://dx.doi.org/10.1016/j. anifeedsci.2010.02.007.

Domínguez, R., Pateiro, M., Gagaoua, M., Barba, F. J., Zhang, W., \& Lorenzo, J. M. (2019). A comprehensive review on lipid oxidation in meat and meat products. Antioxidants, 8(10), 429. http://dx.doi.org/10.3390/ antiox8100429. PMid:31557858.

Fernandes, R. D. P. P., Freire, M. T. D. A., Guerra, C. C., Carrer, C. D. C., Balieiro, J. C. D. C., \& Trindade, M. A. (2012). Estabilidade físico-química, microbiológica e sensorial de carne ovina embalada a vácuo estocada sob refrigeração. Ciência Rural, 42(4), 724-729. http://dx.doi.org/10.1590/S0103-84782012000400025.

Francisco, A., Dentinho, M. T., Alves, S. P., Portugal, P. V., Fernandes, F., Sengo, S., Jerónimo, E., Oliveira, M. A., Costa, P., Sequeira, A., Bessa, R. J. B., \& Santos-Silva, J. (2015). Growth performance, carcass and meat quality of lambs supplemented with increasing levels of a tanniferous bush (Cistus ladanifer L.) and vegetable oils. Meat Science, 100, 275-282. http://dx.doi.org/10.1016/j.meatsci.2014.10.014. PMid:25460137.

Girard, M., Dohme-Meier, F., Silacci, P., Ampuero Kragten, S., Kreuzer, M., \& Bee, G. (2016). Forage legumes rich in condensed tannins may increase n-3 fatty acid levels and sensory quality of lamb meat. Journal of the Science of Food and Agriculture, 96(6), 1923-1933. http://dx.doi.org/10.1002/jsfa.7298. PMid:26059039.

Gravador, R. S., Luciano, G., Jongberg, S., Bognanno, M., Scerra, M., Andersen, M. L., Lund, M. N., \& Priolo, A. (2015). Fatty acids and oxidative stability of meat from lambs fed carob-containing diets. Food Chemistry, 182, 27-34. http://dx.doi.org/10.1016/j. foodchem.2015.02.094. PMid:25842304.

Hernández, B., Sáenz, C., Alberdi, C., \& Diñeiro, J. M. (2016). CIELAB color coordinates versus relative proportions of myoglobin redox forms in the description of fresh meat appearance. Journal of Food Science and Technology, 53(12), 4159-4167. http://dx.doi.org/10.1007/ s13197-016-2394-6. PMid:28115756.

Hopkins, D. L. (2017). The eating quality of meat: II-Tenderness. In F. Toldrá (Ed.), Lawrie's meat science (Chap. 12, pp. 357-381). United Kingdom: Woodhead Publishing. https://doi.org/10.1016/ B978-0-08-100694-8.00012-1.

Jerónimo, E., Pinheiro, C., Lamy, E., Dentinho, M. T., Sales-Baptista, E., Lopes, O., \& Silva, F. (2016). Tannins in ruminant nutrition: impact on animal performance and quality of edible products. In C. A. Combs (Ed.), Tannins: biochemistry, food sources and nutritional properties (Chap. 5, pp. 121-168). New York: Nova Science Publishers.
Jongberg, S., Skov, S. H., Tørngren, M. A., Skibsted, L. H., \& Lund, M. N. (2011). Effect of white grape extract and modified atmosphere packaging on lipid and protein oxidation in chill stored beef patties. Food Chemistry, 128(2), 276-283. http://dx.doi.org/10.1016/j. foodchem.2011.03.015. PMid:25212132.

Jongberg, S., Tørngren, M. A., Gunvig, A., Skibsted, L. H., \& Lund, M. N. (2013). Effect of green tea or rosemary extract on protein oxidation in Bologna type sausages prepared from oxidatively stressed pork. Meat Science, 93(3), 538-546. http://dx.doi.org/10.1016/j. meatsci.2012.11.005. PMid:23273462.

Jung, S., Choe, J. H., Kim, B., Yun, H., Kruk, Z. A., \& Jo, C. (2010). Effect of dietary mixture of gallic acid and linoleic acid on antioxidative potential and quality of breast meat from broilers. Meat Science, 86(2), 520-526. http://dx.doi.org/10.1016/j.meatsci.2010.06.007. PMid:20609528.

Kamel, H. E. M., Al-Dobaib, S. N., Salem, A. Z., López, S., \& Alaba, P. A. (2018). Influence of dietary supplementation with sunflower oil and quebracho tannins on growth performance and meat fatty acid profile of Awassi lambs. Animal Feed Science and Technology, 235, 97-104. http://dx.doi.org/10.1016/j.anifeedsci.2017.11.006.

Khliji, S., Van de Ven, R., Lamb, T. A., Lanza, M., \& Hopkins, D. L. (2010). Relationship between consumer ranking of lamb colour and objective measures of colour. Meat Science, 85(2), 224-229. http://dx.doi.org/10.1016/j.meatsci.2010.01.002. PMid:20374889.

Koleckar, V., Kubikova, K., Rehakova, Z., Kuca, K., Jun, D., Jahodar, L., \& Opletal, L. (2008). Condensed and hydrolysable tannins as antioxidants influencing the health. Mini-Reviews in Medicinal Chemistry, 8(5), 436-447. http://dx.doi.org/10.2174/138955708784223486. PMid:18473933.

Kumar, Y., Yadav, D. N., Ahmad, T., \& Narsaiah, K. (2015). Recent trends in the use of natural antioxidants for meat and meat products. Comprehensive Reviews in Food Science and Food Safety, 14(6), 796812. http://dx.doi.org/10.1111/1541-4337.12156.

Lee, J. H., Min, B. R., \& Lemma, B. B. (2017). Quality characteristics of goat meat as influenced by condensed tannins-containing pine bark. Small Ruminant Research, 146, 28-32. http://dx.doi.org/10.1016/j. smallrumres.2016.11.009.

Lindahl, G., Lundström, K., \& Tornberg, E. (2001). Contribution of pigment content, myoglobin forms and internal reflectance to the colour of pork loin and ham from pure breed pigs. Meat Science, 59(2), 141-151. http://dx.doi.org/10.1016/S0309-1740(01)00064-X. PMid:22062672.

Liu, H., Li, K., Mingbin, L., Zhao, J., \& Xiong, B. (2016). Effects of chestnut tannins on the meat quality, welfare, and antioxidant status of heat-stressed lambs. Meat Science, 116, 236-242. http://dx.doi. org/10.1016/j.meatsci.2016.02.024. PMid:26914512.

Lobón, S., Blanco, M., Sanz, A., Ripoll, G., Bertolín, J. R., \& Joy, M. (2017). Meat quality of light lambs is more affected by the dam's feeding system during lactation than by the inclusion of quebracho in the fattening concentrate. Journal of Animal Science, 95(11), 4998-5011. http://dx.doi.org/10.2527/jas2017.1595. PMid:29293726.

López-Andrés, P., Luciano, G., Vasta, V., Gibson, T. M., Biondi, L., Priolo, A., \& Mueller-Harvey, I. (2013). Dietary quebracho tannins are not absorbed, but increase the antioxidant capacity of liver and plasma in sheep. British Journal of Nutrition, 110(4), 632-639. http://dx.doi. org/10.1017/S0007114512005703. PMid:23312208.

Luciano, G., Monahan, F. J., Vasta, V., Biondi, L., Lanza, M., \& Priolo, A. (2009b). Dietary tannins improve lamb meat colour stability. Meat Science, 81(1), 120-125. http://dx.doi.org/10.1016/j.meatsci.2008.07.006. PMid:22063971. 
Luciano, G., Monahan, F. J., Vasta, V., Biondi, L., Lanza, M., Pennisi, P., \& Priolo, A. (2009a). Lamb meat colour stability as affected by dietary tannins. Italian Journal of Animal Science, 8(Suppl. 2), 507509. http://dx.doi.org/10.4081/ijas.2009.s2.507.

Luciano, G., Vasta, V., Monahan, F. J., López-Andrés, P., Biondi, L., Lanza, M., \& Priolo, A. (2011). Antioxidant status, colour stability and myoglobin resistance to oxidation of longissimus dorsi muscle from lambs fed a tannin-containing diet. Food Chemistry, 124(3), 1036-1042. http://dx.doi.org/10.1016/j.foodchem.2010.07.070.

Lund, M. N., Heinonen, M., Baron, C. P., \& Estévez, M. (2011). Protein oxidation in muscle foods: a review. Molecular Nutrition \& Food Research, 55(1), 83-95. http://dx.doi.org/10.1002/mnfr.201000453. PMid:21207515.

Makkar, H. P., Becker, K., Abel, H. J., \& Szegletti, C. (1995). Degradation of condensed tannins by rumen microbes exposed to quebracho tannins (QT) in rumen simulation technique (RUSITEC) and effects of QT on fermentative processes in the RUSITEC. Journal of the Science of Food and Agriculture, 69(4), 495-500. http://dx.doi.org/10.1002/jsfa.2740690414.

Morales, R., \& Ungerfeld, E. M. (2015). Use of tannins to improve fatty acids profile of meat and milk quality in ruminants: a review. Chilean Journal of Agricultural Research, 75(2), 239-248. http:// dx.doi.org/10.4067/S0718-58392015000200014.

Muíño, I., Apeleo, E., de la Fuente, J., Pérez-Santaescolástica, C., RivasCañedo, A., Pérez, C., Díaz, M. T., Cañeque, V., \& Lauzurica, S. (2014). Effect of dietary supplementation with red wine extract or vitamin $\mathrm{E}$, in combination with linseed and fish oil, on lamb meat quality. Meat Science, 98(2), 116-123. http://dx.doi.org/10.1016/j. meatsci.2014.05.009. PMid:24927047.

Priolo, A., Waghorn, G. C., Lanza, M., Biondi, L., \& Pennisi, P. (2000). Polyethylene glycol as a means for reducing the impact of condensed tannins in carob pulp: effects on lamb growth performance and meat quality. Journal of Animal Science, 78(4), 810-816. http://dx.doi. org/10.2527/2000.784810x. PMid:10784169.

Ripoll, G., Joy, M., \& Muñoz, F. (2011). Use of dietary vitamin E and selenium (Se) to increase the shelf life of modified atmosphere packaged light lamb meat. Meat Science, 87(1), 88-93. http://dx.doi. org/10.1016/j.meatsci.2010.09.008. PMid:20920835.

Stahlke, E. V. R., Rossa, L. S., Silva, G. M., Sotomaior, C. S., Pereira, A. J., Luciano, F. B., Borges, T. D., \& Macedo, R. E. F. (2019). Effects of Modified Atmosphere Packaging (MAP) and slaughter age on the shelf life of lamb meat. Food Science and Technololy, 39(2), 328-335. http://dx.doi.org/10.1590/fst.29617.
Valenti, B., Natalello, A., Vasta, V., Campidonico, L., Roscini, V., Mattioli, S., Pauselli, M., Priolo, A., Lanza, M., \& Luciano, G. (2019). Effect of different dietary tannin extracts on lamb growth performances and meat oxidative stability: comparison between mimosa, chestnut and tara. Animal, 13(2), 435-443. http://dx.doi. org/10.1017/S1751731118001556. PMid:29983123.

Vasta, V., Pennisi, P., Lanza, M., Barbagallo, D., Bella, M., \& Priolo, A. (2007). Intramuscular fatty acid composition of lambs given a tanniniferous diet with or without polyethylene glycol supplementation. Meat Science, 76(4), 739-745. http://dx.doi. org/10.1016/j.meatsci.2007.02.015. PMid:22061252.

Vasta, V., Priolo, A., Scerra, M., Hallett, K. G., Wood, J. D., \& Doran, O. (2009). $\Delta 9$ desaturase protein expression and fatty acid composition of longissimus dorsi muscle in lambs fed green herbage or concentrate with or without added tannins. Meat Science, 82(3), 357-364. http:// dx.doi.org/10.1016/j.meatsci.2009.02.007. PMid:20416712.

Vyncke, W. (1970). Direct determination of the thiobarbituric acid value in trichloroacetic extracts offish as a measure of oxidative rancidity. Fette, Seifen, Anstrichmittel, 72(12), 1084-1087. http:// dx.doi.org/10.1002/lipi.19700721218.

Warner, R. (2014). Measurement of meat quality: measurements of water-holding capacity and color - objective and subjective. In D. Carrick \& D. Michael (Eds.). Encyclopedia of meat sciences (Vol. 2, pp. 164-171). Oxford: Elsevier. http://dx.doi.org/10.1016/B978-012-384731-7.00210-5.

Yisehak, K., Biruk, K., Abegaze, B., \& Janssens, G. P. (2014). Growth of sheep fed tannin-rich Albizia gummifera with or without polyethylene glycol. Tropical Animal Health and Production, 46(7), 1113-1118. http://dx.doi.org/10.1007/s11250-014-0605-6. PMid:24832590.

Zhao, J., Li, K., Su, R., Liu, W., Ren, Y., Zhang, C., Du, M., \& Zhang, J. (2017). Effect of dietary Tartary buckwheat extract supplementation on growth performance, meat quality and antioxidant activity in ewe lambs. Meat Science, 134, 79-85. http://dx.doi.org/10.1016/j. meatsci.2017.07.016. PMid:28763700.

Zhong, R. Z., Fang, Y., Wang, Y. Q., Sun, H. X., \& Zhou, D. W. (2016). Effects of substituting finely ground sorghum for finely ground corn on feed digestion and meat quality in lambs infected with Haemonchus contortus. Animal Feed Science and Technology, 211, 31-40. http://dx.doi.org/10.1016/j.anifeedsci.2015.08.007. 